\title{
Management of plant architecture, spacing and population on the yield of super early common bean
}

\section{Manejo da arquitetura, espaçamento e população na produtividade de feijoeiro superprecoce}

\author{
Cleber Morais GUIMARÃES ${ }^{1}$; Luís Fernando STONE²; Mônica Ferreira de MELO³ \\ ${ }^{1}$ Engenheiro-Agrônomo, Doutor, Embrapa Arroz e Feijão, e-mail: cleber.guimaraes@embrapa.br \\ ${ }^{2}$ Autor para correspondência, Engenheiro-Agrônomo, Doutor, Embrapa Arroz e Feijão, GO, 462, km 12, Santo Antônio de \\ Goiás/GO- CEP 75375-000, e-mail: luis.stone@embrapa.br \\ ${ }^{3}$ Engenheiro-Agrônomo, B.S., Instituto Federal Goiano, Campus Ceres, e-mail: monicafmelo2012@hotmail.com
}

Recebido em: 08-06-2020; Aceito em: 30-06-2020

\begin{abstract}
For efficiency in the use of production factors and maximization of the yield of cultivars, it is essential to determine the most appropriate spatial arrangement for each cultivar and environment. This study identifies the effects of artificial adjustment of plant architecture, spacing between rows, and plant population on the yield of the super early common bean cultivar BRS FC104. We conducted the experiment in randomized blocks with subdivided plots and three replicates. In the plots, we assessed the spacing between rows $(22.5,45.0$, and $67.5 \mathrm{~cm})$. In the subplots, we considered the levels of artificial adjustment of plant architecture (maintenance of one or three lateral branches and control without architecture adjustment). In the subsubplots, we assessed populations of $6,11,16$, and 21 plants per meter. The number of pods per plant increased with the increase in spacing between rows and with the reduction in plant population. Grain weight, in turn, increased with the reduction in spacing between rows and with the increase in plant population up to 14.7 plants per meter. Regarding grain yield and seed economy, the most suitable spatial arrangement for the super early cultivar consists of a $22.5 \mathrm{~cm}$ spacing between rows with about 12 plants per meter. The change in plant architecture, with the removal of lateral branches, is not effective to maximize yield.
\end{abstract}

Additional keywords: lateral branch; spatial arrangement; yield potential.

\section{Resumo}

Para que os fatores de produção sejam aproveitados eficientemente e o potencial produtivo das cultivares maximizado, é imprescindível determinar o arranjo espacial mais adequado para cada cultivar e ambiente. Este trabalho teve por objetivo identificar os efeitos do ajuste artificial da arquitetura das plantas, espaçamentos entrelinhas e populações de plantas na produtividade da cultivar de feijoeiro superprecoce BRS FC104. O experimento foi conduzido em blocos casualizados, com parcelas subsubdivididas e três repetições. Nas parcelas, foram avaliados espaçamentos entrelinhas (22,5; 45,0 e 67,5 cm), nas subparcelas, níveis de ajuste artificial da arquitetura das plantas (manutenção de uma ou três ramificações laterais e testemunha sem ajuste da arquitetura) e, nas subsubparcelas, populações de 6, 11, 16 e 21 plantas por metro. O número de vagens por planta aumentou com o incremento no espaçamento entrelinhas e com a redução na população de plantas. A massa dos grãos, por sua vez, aumentou com a redução no espaçamento entre linhas e com o aumento na população de plantas até o máximo de 14,7 plantas por metro. Considerando a produtividade de grãos e a economia de sementes, o arranjo espacial mais adequado para a cultivar superprecoce consiste no espaçamento de $22,5 \mathrm{~cm}$ entrelinhas com cerca de 12 plantas por metro. A alteração na arquitetura da planta, com a remoção de ramos laterais, não é efetiva para maximizar a produtividade.

Palavras-chave adicionais: arranjo espacial; potencial produtivo; ramificação lateral.

\section{Introduction}

Developing common bean (Phaseolus vulgaris L.) cultivars with early cycle, erect architecture, and high grain yield represents marketing advantages for producers. Early cultivars are important for better planning of sowing and harvest times, in addition to facilitating crop rotation and management practices (Ribeiro et al., 2018). More erect plants, with higher physiological efficiency, facilitate cultural treatments, enable mechanized harvesting, and provide less favorable condi- tions for certain pathogens by facilitating air circulation (Moura et al., 2013; Pires et al., 2014).

The environment usually has a significant influence on plant architecture (Moura et al., 2013). The spatial arrangement of plants affects their architecture, canopy development, and pod distribution. It also affects early soil cover, competition between crops and weeds, evaporation from the soil surface, light interception, lodging, and the development of an ideal number of fruiting sites in the bean canopy (Masa et al., 2017). In cowpea, Bezerra et al. (2009) found that increases in 
population density significantly reduced the number of lateral branches. This reduction implies a decrease in leaf area, especially in denser populations, significantly affecting the production and partition of carbohydrates and grain yield (Saidi et al., 2007).

Variation in the spatial arrangement of bean plants affects several yield components, especially the number of pods and grains per plant. The number of pods is the first formed yield component in the reproductive phase, being negatively affected by the increase in plant population due to the increase in intraspecific competition (Santos et al., 2014). This yield component depends on the number of plant nodes, either in the main branch or in lateral branches. Although the number of pods is important for yield formation, it is unstable, with low heritability, being influenced by morphological and physiological factors of growth and development (Zilio et al., 2011). Plant population also affects the number of grains per pod. An increase in this variable can cause abortion of flowers and grains in the pods, decreasing seed production due to lower availability of photoassimilates in an environment with more competition for light. Hundred grain weight, on the other hand, is the yield component least influenced by plant population since it is a character of qualitative inheritance, little influenced by the environment and controlled by few genes (Santos et al., 2014).

Several authors reported the effects of spatial arrangement on common bean yield and its components. Increasing the number of plants per row or decreasing the spacing between rows decreased the number of pods per plant (Shimada et al., 2000; Santos et al., 2014; Masa et al., 2017; Guimarães et al., 2019), the number of grains per plant (Shimada et al., 2000), and the number of grains per pod (Masa et al., 2017). Moreover, Masa et al. (2017) observed that the increase in the number of plants per row increased leaf area index, plant height, and dry matter, and decreased leaf area and 100-grain weight. The authors also verified an increase in plant height and a decrease in 100-grain weight from a reduction in spacing between rows. This reduction also increased grain yield (Shimada et al., 2000; Masa et al., 2017); however, the effect of increasing plant population on yield is variable: Shimada et al. (2000) observed a decrease in yield, while Masa et al. (2017) reported an increase for this variable. In turn, Silva et al. (2012), Santos et al. (2014), and Guimarães et al. (2019) reported that plant population did not affect yield.

The release of the super early common bean cultivar BRS FC104, of semiprostrate architecture and indeterminate growth habit, aimed to meet the demand of farmers for earlier cultivars to increase operational flexibility in bean production systems, allowing higher land use efficiency (Gonzaga, 2017).

Recommendations for common bean cropping include a spacing of 40 to $50 \mathrm{~cm}$ between rows, with 10 to 15 seeds per meter (Araújo \& Camelo, 2015). Notwithstanding, cultivars with fewer branches fit better to higher plant populations per area (Bezerra et al., 2009; Santos et al., 2014). In addition, early cultivars usually have fewer nodes in the main stem (Moura et al., 2013; Zilio et al., 2013) and fewer lateral branches. Thus, as the number of branches correlates positively and significantly with bean yield (Zilio et al., 2013; Ejara et al., 2017), early cultivars require a differentiated spatial arrangement to maximize yield.

In view of the above, this study identifies the effects of artificial adjustment of plant architecture, spacing between rows, and plant populations on the yield of the super early bean cultivar BRS FC104.

\section{Material and methods}

We conducted the experiment from June to August 2018 in Santo Antônio de Goiás city, Goiás State, Brazil (16 ${ }^{\circ} 30^{\prime} 13.23^{\prime \prime} S$ and 49 $16^{\prime}$ 54.73" W). According to the Köppen classification, the climate of the region is Aw, tropical savanna, megathermic.

We used the super early bean cultivar BRS FC104. We conducted the experiment in randomized blocks with subdivided plots and three replicates. In the plots, we assessed the spacing between rows (22.5, 45.0 , and $67.5 \mathrm{~cm}$ ). In the subplots, we considered three levels of artificial adjustment of plant architecture (maintenance of one or three lateral branches and control without architecture adjustment). In the subsubplots, we assessed four plant populations $(6,11,16$, and 21 plants per meter). We arranged these populations in 3, 2, and 1 five-meter rows, respectively, for the spacings of $22.5,45.0$, and $67.5 \mathrm{~cm}$. The useful area consisted of 2, 1 , and 1 two-meter rows, respectively.

The soil of the experimental area is a clayey Acric Red Oxisol, whose chemical analysis showed the following results; $\mathrm{pH}\left(\mathrm{H}_{2} \mathrm{O}\right)=5.5 ; \mathrm{Ca}=13.5 \mathrm{mmol}_{\mathrm{c}} \mathrm{dm}^{-3}$; $\mathrm{Mg}=9.2 \mathrm{mmol}_{\mathrm{c}} \mathrm{dm}^{-3} ; \mathrm{Al}=1 \mathrm{mmol}_{\mathrm{c}} \mathrm{dm}^{-3} ; \mathrm{P}=7.3 \mathrm{mg} \mathrm{dm}^{-3}$; $\mathrm{K}=61 \mathrm{mg} \mathrm{dm}^{-3} ; \mathrm{Cu}=0.9 \mathrm{mg} \mathrm{dm}^{-3} ; \mathrm{Zn}=3.3 \mathrm{mg} \mathrm{dm}^{-3}$; $\mathrm{Fe}=25 \mathrm{mg} \mathrm{dm}^{-3} ; \mathrm{Mn}=11.1 \mathrm{mg} \mathrm{dm}^{-3}$; and organic matter $=33.0 \mathrm{~g} \mathrm{~kg}^{-1}$. Fertilization at sowing consisted of $108 \mathrm{~kg} \mathrm{ha}^{-1} \mathrm{P}_{2} \mathrm{O}_{5}$ and $20 \mathrm{~kg} \mathrm{ha}^{-1} \mathrm{~N}$, which we applied on $06 / 06 / 2018$. Topdress fertilization consisted of $70 \mathrm{~kg} \mathrm{ha}^{-1}$ $\mathrm{N}$, which we applied 22 days after sowing. The other agronomic managements followed the recommendations for the crop (Carneiro et al., 2015).

We pruned the lateral branches, with the aid of scissors, when the plants were in the phenological stage V4 (36 days after sowing), at the beginning of the development of secondary branches. After pruning all plots, we restarted the process, eliminating the branches immediately after their emission to reduce the energetic wear of plants with the emission and growth of lateral branches. We completed the pruning cycle when the plants were at R7 (63 days after sowing). This period corresponded to the beginning of pod development, when the canopy of the plants was well closed; thus, pruning would damage the plants and compromise yield.

We determined the number of pods per plant and the number of grains per pod of all plants in the useful area of each subplot. We determined hundred grain weight by the average weight of two 100-grain samples. We determined grain yield from the grain 
weight in the useful area, which we corrected to $13 \%$ moisture; we expressed the results in $\mathrm{kg} \mathrm{ha}^{-1}$. We submitted the data to analysis of variance by the $F$ test, using the GLM procedure of the SAS statistical program (SAS Institute, 1999). We compared the means by the Tukey's test at 0.05 probability. In addition, we performed regression analysis for significant spacing and plant population effects.

\section{Results and discussion}

There was no interaction between treatments,

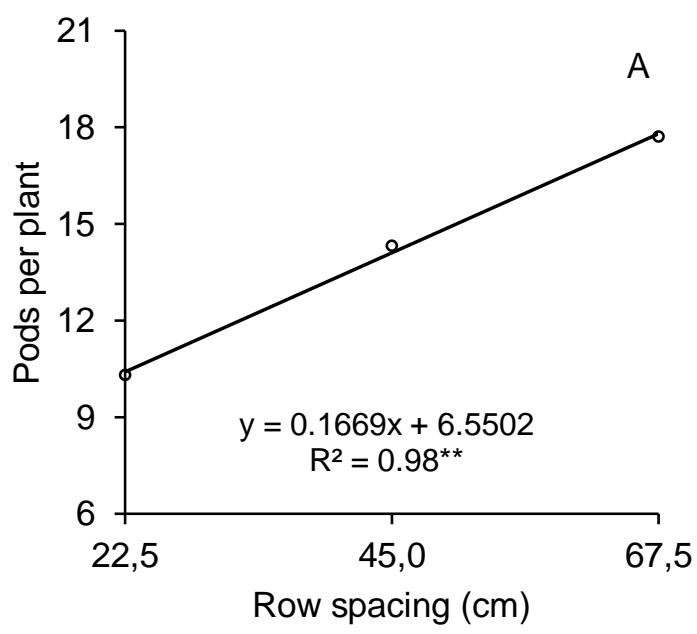

but rather an isolated effect of the factors. The number of pods per plant increased linearly with the spacing between the rows (Figure 1A) and decreased with the increase in plant population following the quadratic polynomial model (Figure 1B). This corroborates the results of Shimada et al. (2000), Santos et al. (2014), Masa et al. (2017), and Guimarães et al. (2019). Regarding plant populations, the one that enabled the highest number of pods (18.3 pods) was 6 plants per meter. The number of pods decreased until the population of 21 plants per meter, in which the number of pods was 11.4 , with a reduction of $38 \%$.

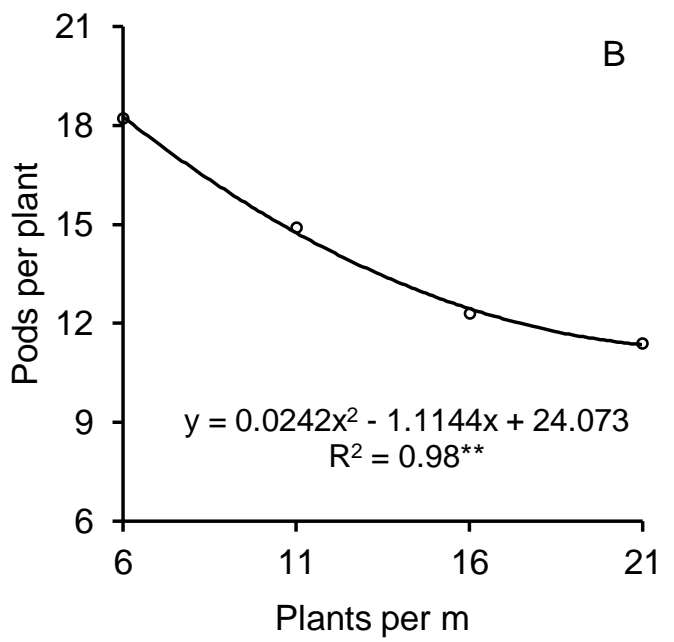

Figure 1 - Effect of row spacing $(A)$ and plant population per meter $(B)$ on the number of pods per plant of super early bean 'BRS FC104'.

According to White \& Izquierdo (1989), competition for light in larger populations results in low availability of carbohydrates, not meeting the demand for all the developing flowers and pods, leading to abscess formation in these organs. Flowers and pods at an early stage of development are less competitive and are therefore aborted. Furthermore, carbohydrates may not move quickly enough to the developing flowers and pods because the vascular system in the peduncle is not fully operational. Axillary flowers with short peduncles and with a large cross-section and large leaves near the drain can increase the yield potential of genotypes by reducing resistance to carbohydrate flow.

Due to the plasticity of common bean, its yield can increase even with the reduction of the number of pods per plant from the increase in plant population. Hence the importance of maintaining flowering and fertilizing ovules with an adequate supply of nutrients, especially in high plant populations.

The number of grains per pod showed a trend of linear increase with the increase in spacing between rows, in agreement with Masa et al. (2017) and
Guimarães et al. (2019). In turn, the number of plants per row did not influence this variable, corroborating the results of Santos et al. (2014) and Guimarães et al. (2019). According to Santos et al. (2014), environmental conditions influence the number of grains per pod more than plant population.

The increase in spacing between rows decreases the competition between plants for available light, therefore increasing their photosynthesis capacity and carbohydrate availability. On the other hand, the reduction in spacing increases mutual shading and respiration, and decreases photosynthesis. Low availability of carbohydrates for grains during pod development decreases grain weight and causes grain abortion, with consequent reduction in the number of grains per pod.

Hundred grain weight decreased linearly with the increase in spacing between rows (Figure 2A). Moreover, the variable followed the quadratic polynomial model for the increase in the number of plants per row (Figure 2B), reaching the maximum value of $27.07 \mathrm{~g}$ with 14.7 plants per meter. 

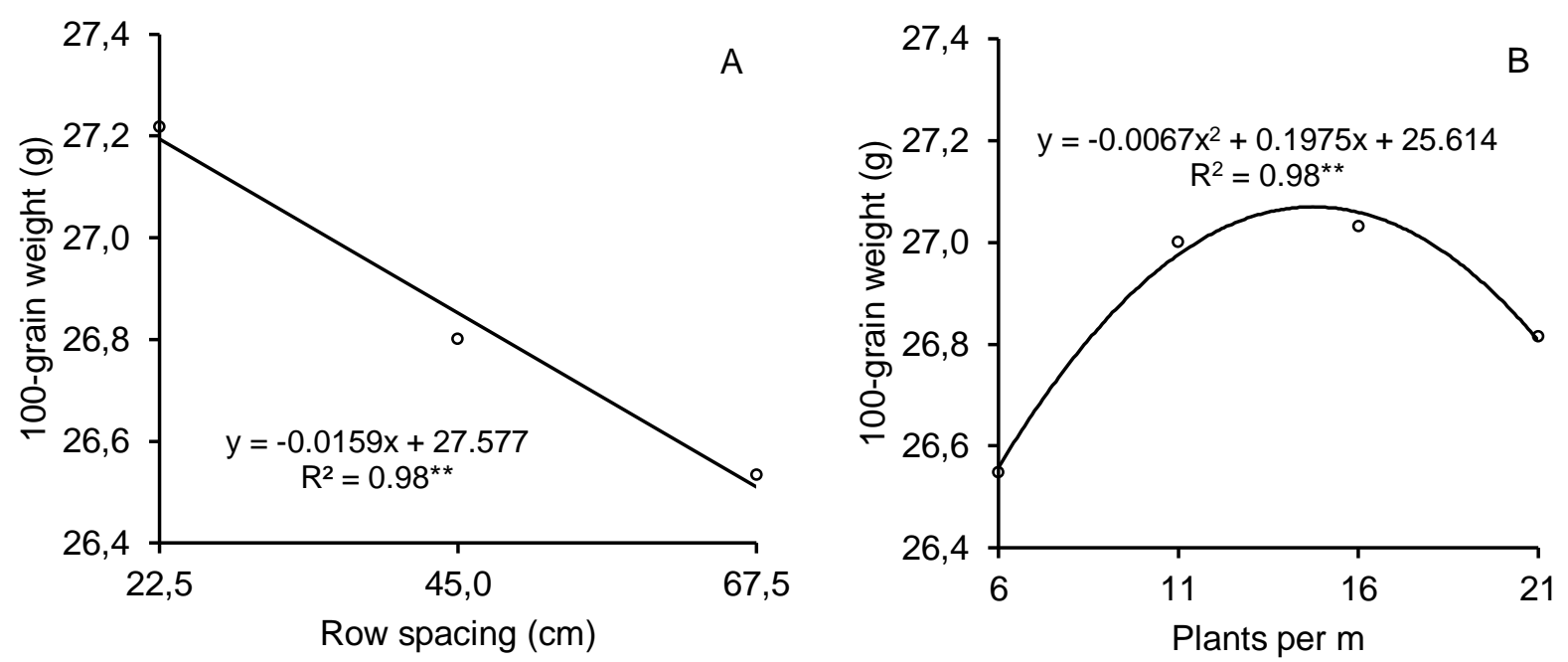

Figure 2 - Effect of row spacing (A) and plant population per meter (B) on 100-grain weight of super early bean 'BRS FC104'.

The increase in 100-grain weight from both the decrease in spacing between rows and the increase in the number of plants per row was probably due to the reduction in the number of pods per plant in these situations. The reduction in the size of the carbohydrate storage site from the reduction in the number of pods per plant made more carbohydrates available for the formation of grains that were present in lesser numbers in plants. The increase in 100-grain weight reached a maximum after which the high number of plants caused an excessive increase in leaf area, with consequent mutual shading. This leads to carbohydrate consumption for respiration and to low photosynthesis. Zilio et al. (2011) report that, due to the plasticity of bean plants, a compensation between the number of pods per plant and grain weight is common when there is a change in spacing between rows.

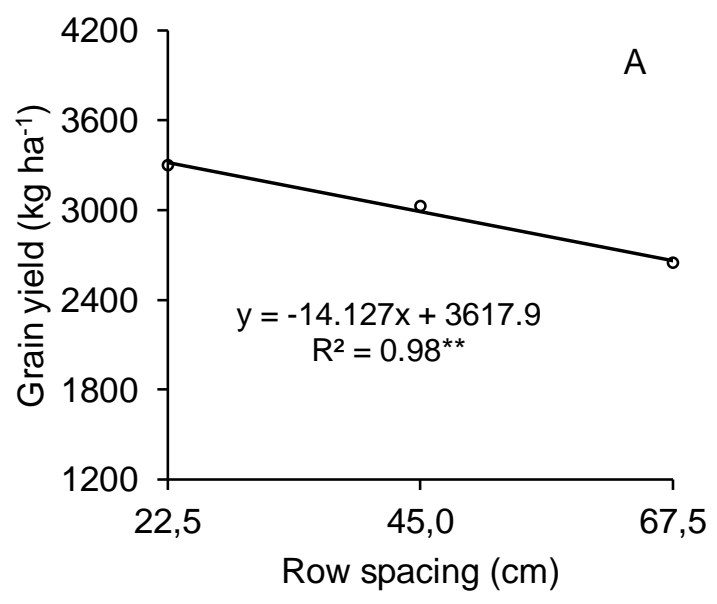

Yield increased with the decrease in spacing between rows (Figure 3A), corroborating the results of Shimada et al. (2000) and Masa et al. (2017). This variable also increased with the increase in the number of plants per row (Figure 3B), corroborating Masa et al. (2017). The maximum yield ( $3156 \mathrm{~kg} \mathrm{ha}^{-1}$ ) occurred with 18.6 plants per meter. For the cultivar BRS FC104 sown in a 45-cm spacing, Gonzaga (2017) found a linear increase in yield up to the largest population of the experiment, 20 plants per meter. An economic criterion for the recommendation of input dose is maximum technical efficiency, that is, $90-95 \%$ of the maximum yield (Santos et al., 2019). Thus, considering seed economy, it is possible to recommend a population of 11.6 plants per meter, corresponding to $95 \%$ of the maximum yield, $2998 \mathrm{~kg} \mathrm{ha}^{-1}$.

Figure 3 - Effect of row spacing (A) and plant population per meter (B) on grain yield of super early bean 'BRS FC104'.

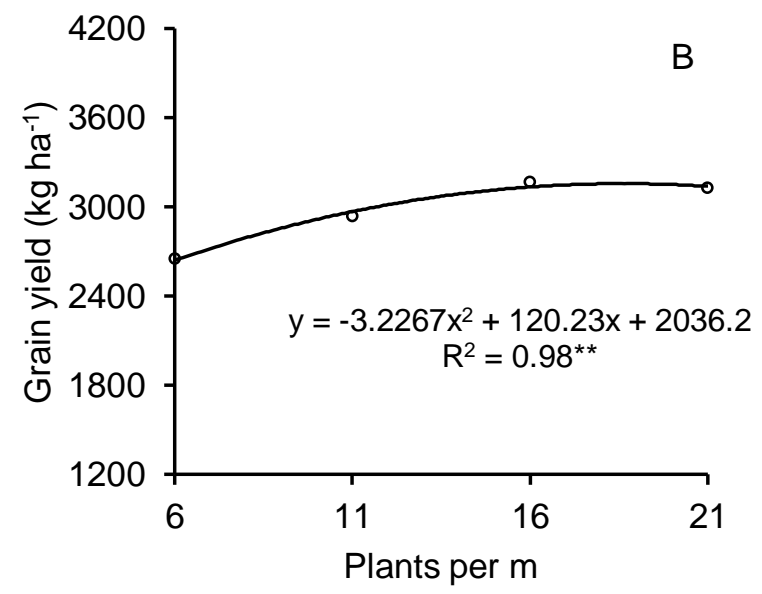


The yield response to both the spacing between rows and the number of plants per row relates to the 100-grain weight (Figure 2) and the higher number of plants per area. Ejara et al. (2017) and Ribeiro et al. (2018) reported a significant and positive correlation between 100-grain weight and yield in bean.
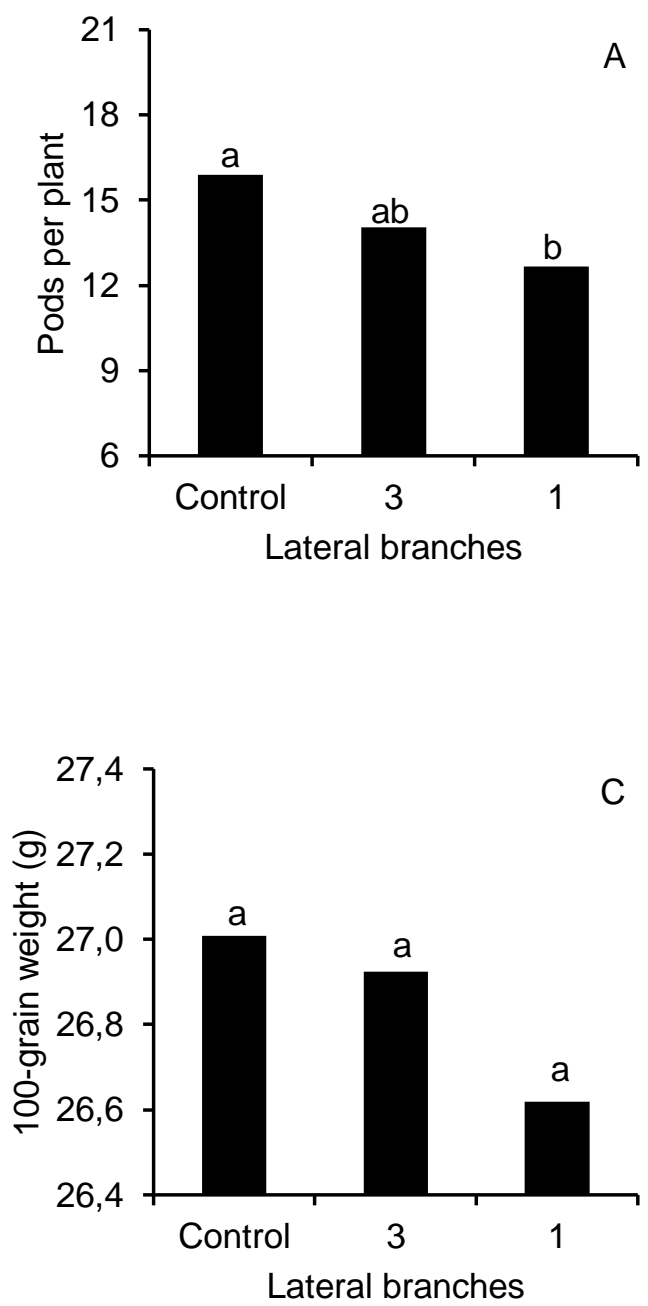

The removal of lateral branches resulted in a lower number of pods per plant and had no significant effect on number of grains per pod and 100-grain weight (Figure 4). This corroborates Ribeiro et al. (2018), who found a positive correlation between the number of branches and the number of pods per plant.
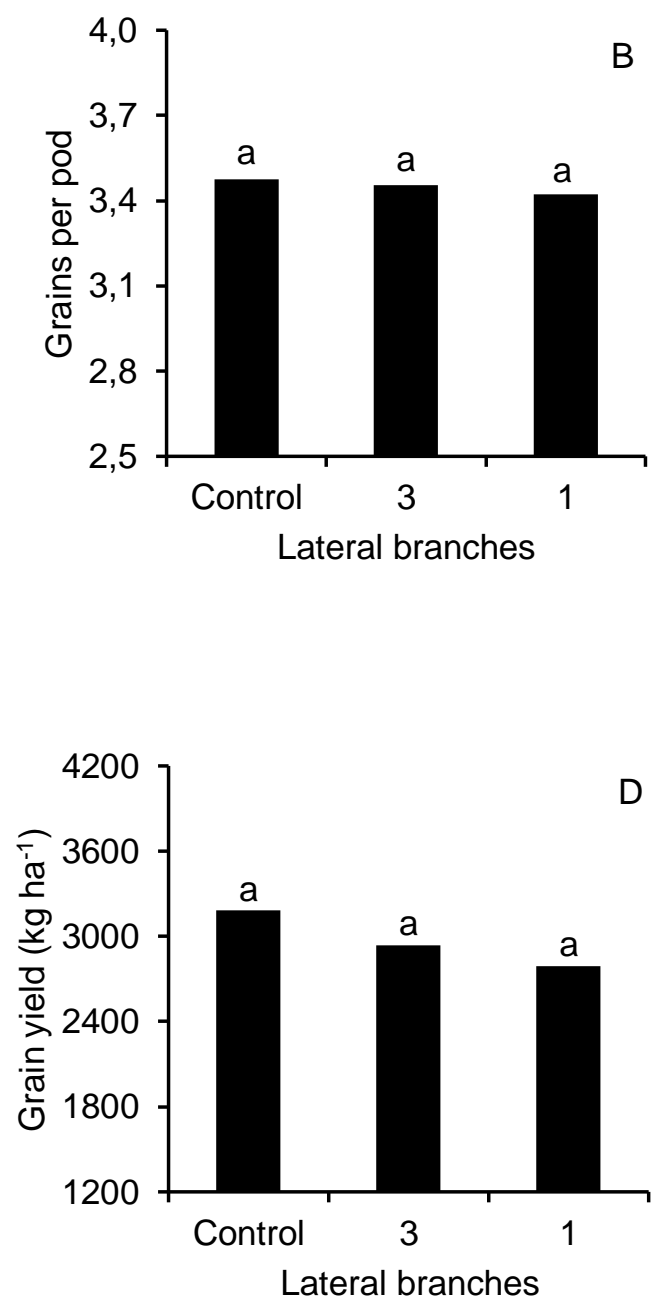

Figure 4 - Effect of number of lateral branches on number of pods per plant $(A)$ and grains per pod (B), 100-grain weight (C) and grain yield (D) of super early bean 'BRS FC104'.

The removal also did not significantly affect yield, although there was a downward trend, with yields of 2790,2937 , and $3184 \mathrm{~kg} \mathrm{ha}^{-1}$, respectively, for plots containing plants with one lateral branch, three lateral branches, and with normal development (without removal of lateral branches). These yields are above the average for Goiás State in 2018 (third harvest), which was $2746 \mathrm{~kg} \mathrm{ha}^{-1}$ (Embrapa, 2020).

Source-sink relationships are a determining factor in bean yield. The higher the number of reproductive nodes (those that, in addition to the vegetative organs, also have raceme), the higher the number of pods and the yield (Zilio et al., 2011). According to Saidi et al. (2007), reduction in the number of lateral branches implies a decrease in leaf area, which significantly affects the production and partition of carbohydrates and grain yield. The reduction of the photosynthetically active area reduces yield components due to a decrease in the production of photoassimilates (Pratissoli et al., 2012). These authors found that increases in the levels of artificial defoliation of common bean decreased the number of pods per plant, 100-grain weight, and yield.

\section{Conclusions}

The number of pods per plant increases with the increase in spacing between rows and with the decrease in plant population. Grain weight, in turn, increases with the decrease in spacing between rows and with the increase in plant population up to a maxi- 
mum of 14.7 plants per meter. Considering grain yield and seed economy, the most suitable spatial arrangement for the super early cultivar consists of a $22.5 \mathrm{~cm}$ spacing between rows with about 12 plants per meter. The change in plant architecture, with the removal of lateral branches, is not effective to maximize yield.

\section{References}

Araújo GAA, Camelo GN (2015) Preparo do solo e plantio. In: Carneiro JE, Paula Júnior TJ, Borém A (ed) Feijão: do plantio à colheita, UFV. p.115-144.

Bezerra AAC, Távora FJAF, Freire Filho FR, Ribeiro VQ (2009) Características de dossel e de rendimento em feijão-caupi ereto em diferentes densidades populacionais. Pesquisa Agropecuária Brasileira 44(10):1239-1245. Doi: http://dx.doi.org/10.1590/S0100-204X2009001000005

Carneiro JE, Paula Júnior TJ de, Borém A (2015) Feijão: do plantio à colheita. UFV. 384p.

Ejara E, Mohammed W, Amsalu B (2017) Correlations and path coefficient analyses of yield and yield related traits in common bean accessions (Phaseolus vulgaris L.) at Abaya and Yabello, Southern Ethiopia. International Journal of Plant Breeding and Crop Science 4(2):215-224.

Embrapa (2020) Socioeconomia. Disponível em: <http://www.cnpaf.embrapa.br/socioeconomia/index.ht $\mathrm{m}>$ (Acesso em 22 jun 2020).

Gonzaga ACO (2017) Densidade de plantas e fornecimento de nitrogênio para a cultivar de feijão-comum superprecoce BRS FC104. UFU (Dissertação de mestrado em Agronomia).

Guimarães CM, Stone LF, Silveira PM, Sarmento PHL (2019) Componentes agronômicos do feijoeiro superprecoce BRS FC104 em diferentes arranjos espaciais e adubações fosfatadas. Colloquium Agrariae 15(3):4048. doi: 10.5747/ca.2019.v15.n3.a297

Masa M, Tana T, Ahmed A (2017) Effect of plant spacing on yield and yield related traits of common bean (Phaseolus vulgaris L.) varieties at Areka, Southern Ethiopia. Journal of Plant Biology \& Soil Health 4(2):113. doi: https://doi.org/10.13188/2331-8996.1000020

Moura MM, Carneiro PCS, Carneiro JES, Cruz CD (2013) Potencial de caracteres na avaliação da arquitetura de plantas de feijão. Pesquisa Agropecuária Brasileira 48(4):417-425. doi: 10.1590/S0100204X2013000400010

Pires LPM, Ramalho MAP, Abreu AFB, Ferreira MC (2014) Recurrent mass selection for upright plant architecture in common bean. Scientia Agricola 71(3):240-243. doi: https://doi.org/10.1590/S010390162014000300009
Pratissoli D, Schmildt ER, Amaral JAT, Schmildt O (2012) Níveis de desfolha artificial para simular perdas na produtividade do feijoeiro comum. Scientia Agraria Paranaensis 11(3):68-76. doi: http://dx.doi.org/10.18188/1983-1471/sap.v11n3p68-76

Ribeiro ND, Santos GG, Maziero SM, Steckling SM (2018) Phenological, plant architecture, and grain yield traits on common bean lines selection. Revista Caatinga 31(3):657-666. doi: doi.org/10.1590/198321252018v31n314rc

Saidi M, Ngouajio M, Itulya FM, Ehlers J (2007) Leaf harvesting initiation time and frequency affect biomass partitioning and yield of cowpea. Crop Science 47(3):1159-1166. doi: https://doi.org/ 10.2135/cropsci2006.06.0420

Santos AB dos, Silva, MAS da, Silveira PM da, Carvalho GD, Stone LF (2019) Nitrogen sufficiency index for estimating nitrogen fertilizer requirement of irrigated rice. Pesquisa Agropecuária Brasileira 66(6):422-430. doi: http://10.1590/0034-737X201966060003

Santos MGP, Carvalho AJ, David AMSS, Amaro HTR, Vieira NMB, Souza VB, Carneiro JES (2014) Densidades de semeadura e safras de cultivo no desempenho produtivo de cultivares de feijoeiro-comum. Semina: Ciências Agrárias 35(5):2309-2324. doi: http://dx.doi.org/10.5433/16790359.2014v35n5p2309

SAS Institute (1999) Procedure guide for personal computers. SAS Institute. 552p.

Shimada MM, Arf O, Sá ME (2000) Componentes do rendimento e desenvolvimento do feijoeiro de porte ereto sob diferentes densidades populacionais. Bragantia 59(2):181-187. doi: https://doi.org/10.1590/S0006-87052000000200009

Silva RR, Scariotto S, Malagi G, Marchese JA (2012) Análise de crescimento em feijoeiro cultivado sob diferentes densidades de semeadura. Scientia Agraria 13(2):41-51.

http://dx.doi.org/10.5380/rsa.v13i2.40883

doi:

White W, Izquierdo J (1989) Dry bean: physiology of yield potential and stress tolerance. FAO Regional Office for Latin America and the Caribbean. 81p.

Zilio M, Coelho CMM, Souza CA, Santos JCP, Miquelluti DJ (2011) Contribuição dos componentes de rendimento na produtividade de genótipos crioulos de feijão (Phaseolus vulgaris L.). Revista Ciência Agronômica 42(2):429-438. doi: https://doi.org/10.1590/S1806-66902011000200024

Zilio M, Souza CA, Coelho CMM, Miquelluti DJ, Michels AF (2013) Cycle, canopy architecture and yield of common bean genotypes (Phaseolus vulgaris) in Santa Catarina State. Acta Scientiarum. Agronomy 35(1):21-30.doi: https://doi.org/10.4025/actasciagron.v35i1.15516 